\title{
Modeling the LFP footprint of unitary thalamic inputs to sensory cortex
}

\author{
Espen Hagen ${ }^{1 *}$, Janne C Fossum ${ }^{1}$, Klas H Pettersen ${ }^{1}$, Jose-Manuel Alonso ${ }^{2}$, Harvey A Swadlow ${ }^{3}$, Gaute T Einevoll ${ }^{1}$ \\ From Twentieth Annual Computational Neuroscience Meeting: CNS*2011 \\ Stockholm, Sweden. 23-28 July 2011
}

The depth-resolved synaptic local-field potential (LFP) footprint in sensory cortex following firing in individual thalamic projection neurons can be accurately measured by averaging cortical multielectrode (ME) LFP signals over thousands of spontaneous thalamic firing events $[1,2]$. This spike-triggered LFP method offers a unique window into the thalamocortical connection. However, the interpretation of the detailed spatiotemporal profile of this LFP footprint is not trivial as the LFP signal reflects a weighted sum over contributions from all dendritic transmembrane currents located in the vicinity of the recording electrode [3]. We here present results from a biophysically detailed computational study of this LFP footprint, focusing on the thalamocortical LFP response in layer 4 of rodent barrel cortex [1]. As illustrated in Fig. 1, the model considers large populations of synaptically activated RS (regular spiking cells) and/or FS (fast-spiking cells) (Fig. 1AB). The computational model, implemented in Python with NEURON, is constrained to predict plausible intracellular EPSCs [4] (Fig. 1C) and EPSPs (Fig. 1D). The model not only predicts the LFP (Fig. 1E), but also the ground-truth CSD
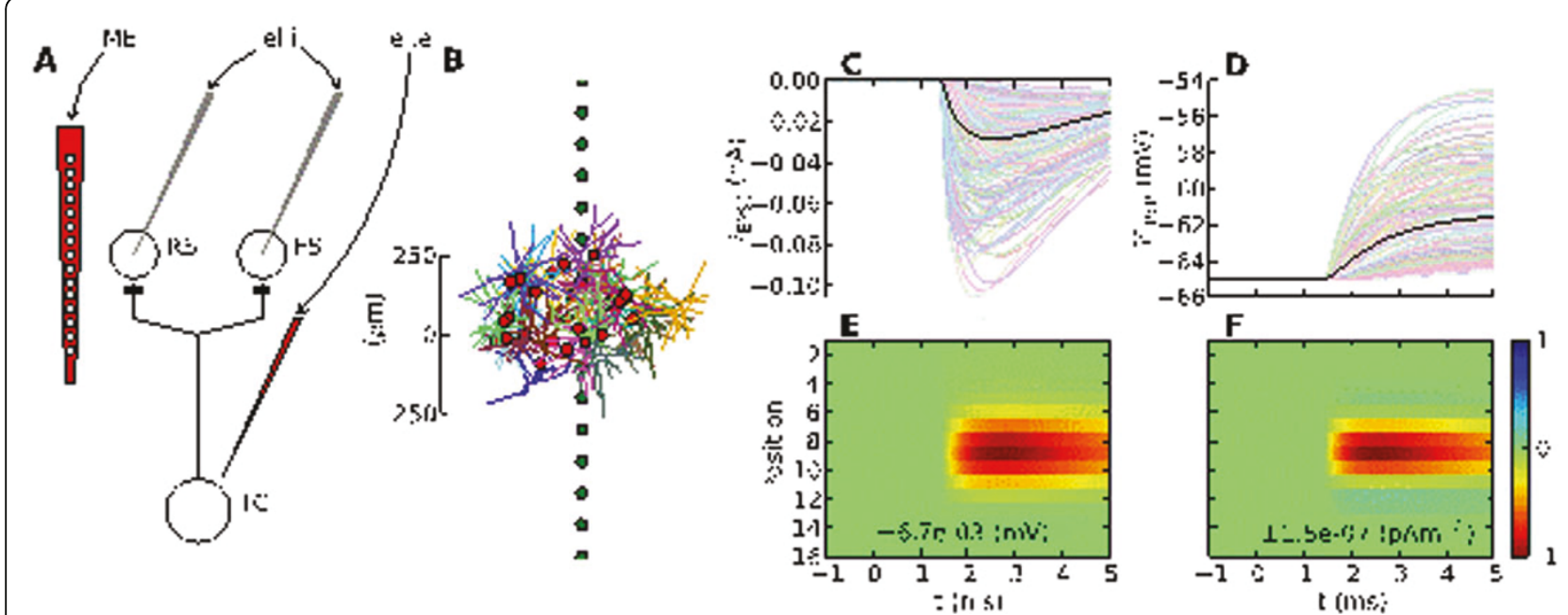

Figure 1 Model overview. A. Schematic of recording of unitary thalamic projection pattern to layer 4 with thalamic single-unit electrode (el.e), cortical clamp electrodes (el.i) and cortical multielectrode (ME) $[1,2,4]$. B. Example model population of reconstructed RS cells with ME penetrating population. C. EPSCs of model population, black line: average EPSC. D. EPSPs of model population, black line: average EPSP. E. ME LFP response F. 'Ground truth' CSD.

\footnotetext{
* Correspondence: espen.hagen@umb.no

'Dept. of Mathematical Sciences \& Technology, Norwegian Univ. Life

Sciences, Ås, NO-1432, Norway

Full list of author information is available at the end of the article
} 
(current source-density) (Fig. 1F) that can be used to test CSD estimation methods [5]. Candidate models mimicking experimental findings $[1,2]$ will be presented.

\section{Acknowledgements}

Supported by the Research Council of Norway (NevroNor, eNEURO, Notur).

\section{Author details}

'Dept. of Mathematical Sciences \& Technology, Norwegian Univ. Life Sciences, Ås, NO-1432, Norway. ${ }^{2}$ Dept. of Biological Sciences, SUNY College of Optometry, NY 10036, USA. ${ }^{3}$ Dept. of Psychology, University of

Connecticut, Storrs, CT 06269, USA.

Published: 18 July 2011

\section{References}

1. Swadlow HA, Gusev AG, Bezdudnaya T: Activation of a cortical column by a thalamocortical impulse. J Neurosci 2002, 22:7766-7773.

2. Jin J, Wang Y, Swadlow HA, Alonso JM: Population receptive fields of ON and OFF thalamic inputs to an orientation column in visual cortex. Nat Neurosci 2011, 14:232-238.

3. Pettersen $\mathrm{KH}$, Hagen $\mathrm{E}$, Einevoll GT: Estimation of population firing rates and current source densities from laminar electrode recordings. $J$ Comp Neurosci 2008, 24:291-313.

4. Hull C, Isaacson JS, Scanziani M: Postsynaptic mechanisms govern the differential excitation of cortical neurons by thalamic inputs. J Neurosci 2009, 29:9127-9136.

5. Pettersen KH, Devor A, Ulbert I, Dale AM, Einevoll GT: Current-source density estimation based on inversion of electrostatic forward solution: Effects of finite extent of neuronal activity and conductivity discontinuities. J Neurosci Methods 2006, 154:116-133.

doi:10.1186/1471-2202-12-S1-P86

Cite this article as: Hagen et al:: Modeling the LFP footprint of unitary thalamic inputs to sensory cortex. BMC Neuroscience 2011 12(Suppl 1): P86.

\section{Submit your next manuscript to BioMed Central} and take full advantage of:

- Convenient online submission

- Thorough peer review

- No space constraints or color figure charges

- Immediate publication on acceptance

- Inclusion in PubMed, CAS, Scopus and Google Scholar

- Research which is freely available for redistribution

Submit your manuscript at www.biomedcentral.com/submit
Ciomed Central 